\title{
PELATIHAN PEMBUATAN MEDIA \\ PEMBELAJARAN KREATIF DARI BARANG BEKAS \\ BAGI GURU- GURU SD DI KECAMATAN WONOSALAM JOMBANG JAWA TIMUR
}

\author{
Putri Rachmadyanti'), Ganes Gunansyah $^{2)}$ FX Mas Subagio ${ }^{3)}$ \\ Prodi PGSD, Fakultas Ilmu Pendidikan, Universitas Negeri Surabaya ${ }^{1,2,3}$ \\ Email: putri.rachmadyanti@gmail.com
}

\section{ARTICLE INFO}

Article History:

Accepted 10 Februari 2019

Available Online 5 April 2019

\section{Keywords:}

media pembelajaran, barang

bekas, Sekolah Dasar

\begin{abstract}
Kegiatan ini bertujuan untuk memberikan pemahaman secara teoritis maupun praktis tentang merancang dan membuat media pembelajaran dari barang bekas. Melalui pelatihan ini diharapkan guruguru semakin termotivasi untuk meranang da membuat media pembelajaran yang efektif dan efisien. Peserta pelatihan adalah keseluruhan guru guru SD yang tergabung dalam Kelompok kera Guru se-Kecamatan Wonosalam Kabuaten Jombang. Metode yang dilaksanakan berupa penyampaian materi serta pendampingan pembuatan media pembelajaran melalui diskusi kelompok. Hasil dari kegiatan pelatihan ini berupa terciptanya berbagai bentuk media pembelajaran dari barang bekas yang data digunakan di kelas dalam pembelajaran di Sekolah Dasar, baik di kelas rendah maupun kelas tinggi.. Hasil angket respon yang dibagikan menunjukkan hasil $90 \%$ guru memamahi materi pelatihan, $85 \%$ merasa puas dengan pembimbingan , dan 87 puas dengan metode saat menyajikan materi dan membimbing. Adapun kendala yang dihadapi adalah keterbatasan waktu pelatihan, sehingga perlu adanya tambahan waktu agar hasil yang didapatkan maksimal.
\end{abstract}

\section{PENDAHULUAN}

Kompetensi professional atau akademis merupakan salah satu kompetensi yang harus dimiliki oleh seorang guru. Hal ini seperti tercantum dalam Undang-Undang Nomor 14 tahun 2005 pasal 10 ayat 1 tentang guru dan dosen. Kompetensi professional 
ini tak terkecuali juga harus dimilki oleh Guru Sekolah Dasar (SD), sebagai pembangun generasi bangsa sejak usia dini. Guru SD diharapkan mampu merencanakan dan mengelola pembelajaran dengan baik sebagai bagian dari penerapan kompetensi profesional yang dimiliki. Perencanaan dan pengelolaan pembelajaran pembelajaran meliputi pembuatan perangkat pembelajaran, menyiapkan media dan lingkungan belajar yang efektif untuk siswa agar tercapai tujuan pembelajaran dengan maksimal.

Jombang merupakan salah kota yang terletak di bagian tengah Provinsi Jawa Timur. Kabupaten Jombang terdiri dari 21 Kecamatan yang mencangkup 306 desa dan 4 kelurahan. Salah satu kecamatan yang ada di Kabupaten yang cukup terkenal adalah Kecamatan Wonosalam. Kecamatan ini terletak di kaki dan lereng Gunung Anjasmoro dengan ketinggian rata-rata 500-600 meter di atas permukaan laut. Wonosalam dikenal sebagai salah satu kota penghasil durian terbesar di Jawa Timur. Dalam bidang pendidikan, Wonosalam memiliki 23 Sekolah Dasar (SD) Negeri yang tersebar di seluruh wilayah Wonosalam.

Karakteristik guru- guru SD di wilayah Wonosalam ini sebagian sudah menerapkan pembelajaran Kurikulum 2013. Pembelajaran K13 ini menuntut guru untuk selalu kreatif dalam mernacang pembelajaran, salah satunya merancang media pembelajaran. Permasalahan yang selama ini dihadapi oleh guru SD di Kecamatan Wonosalam adalah keterbatasan media pembelajaran yang ada di sekolah (media siap pakai), kurangnya pemahaman guru tentang pembuatan media pembelajaran kreatif, serta kurangnya motivasi guru untuk melaksankan pembelajaran dengan menggunakan media yang efektif, efisien, kreatif dan inovatif karena keterbatasan biaya, waktu, dan lain- lain.

Secara teori, guru sebagai fasilitator dalam kegiatan pembelajaran ditunut untuk mampu membuat pembelajaran yang menyenangkan. Salah satu cara dalam membuat pembelajaran yang menyenangkan, yakni guru diharapkan mampu membuat media pembelajaran yang menarik minat dan motivasi siswa. Secara harfiah, media berarti perantara atau pengantar, yang membantu guru dalam menyampaikan pesan berupa informasi/ pengetahuan kepada siswa. Media adalah tempat atau sesuatu yang digunakan sebagai pengantar atau perantara (Arsyad, 2014:3). Adapun pendapat Satrianawati (2018: 7) juga menyebutkan bahwa guru harus mencari, memilih, dan menggunakan sumber belaar serta media pembelajaran yang tepat sesuai dengan tujuan dan materi pembelaaran. Selain itu media pembelajaran yang dirancang sendiri oleh guru diharapakan mampu memenuhi asas efektif dan efisen, misalnya media pembelajaran yang dibuat oleh guru dapat berasal dari barang- barang bekas yang mudah ditemui di lingkungan sekitar.

Sampah atau barang bekas cukup banyak ditemui di sekitar lingkungan. Bagi masyarakat umum, barang bekas hanya dianggap sampah biasa. Pribadi (2017:13) menegaskan bahwa media pembelajaran juga memiliki peran sebagai jembatan dalam proses belajar mengajar untuk menyampaikan dan mengirimkan pesan informasi kepada khalayak. Bagi guru kreatif, barang bekas adalah sumber inspirasi membuat media pembelajaran. Hal ini sejalan dengan pendapat Kustiawan (2016 :211) bahwa kreatifitas guru dalam menggunakan barang bekas menjadi sumber belajar dapat 
membantu proses pendidikan dengan tidak terbatas. Pemanfatan lingkungan sebagai sumber belajar tentu memudahkan siswa dalam memahami informasi. Lalu karena bahan dasarnya adalah bahan bekas, maka aspek kebersihan dan keamanan juga harus dipastikan terpenuhi. Sehingga anak terhindar dari penyakit atau kecelakaan. Contoh barang-barang bekas yang dapat dijadikan media pembelajaran adalah botol plastik, tutup botol plasik, plastik bekas snack, plastik bungkus ditergen atau sabun cuci, kardus atau kertas, limbah kayu, bahkan cangkang telur bisa digunakan sebagai bahan media pembelajaran kreatif.

Pemanfaatan barang bekas dan peralatan sederhana sebagai media bukanlah hal yang baru dalam dunia pendidikan. Sebelum pendidikan modern hadir, para guru telah menggunakan berbagai media dan alat peraga buatannya sendiri untuk menjelaskan materi pelajarannya. Para guru zaman dulu mungkin lebih banyak memiliki kreativitas karena dipaksa oleh keadaan yang masih serba terbatas. Guru harus bekerja keras setiap saat supaya para siswanya bisa belajar dan menyerap materi pelajaran semaksimal mungkin. Oleh karena itu, kegigihan seorang guru dalam menyediakan media pembelajaran walaupun keadaan terbatas ini harus terus dipupuk oleh calon guru maupun guru yang ada di zaman sekarang. Hal ini tentu merujuk dari pengalaman dan kenyataan kondisi SD di Indonesia saat ini belum sepenuhnya memiliki fasilitas yang lengkap dan letak sekolah yang terpencil. Semangat untuk memberikan pembelajaran yang menarik dan kreatif harus tetap ada dalam sanubari Abdi Negara.

Keberhasilan guru dalam menggunakan barang bekas sebagai media pembelajaran terbukti dari adanya beberapa penelitian yang relevan, yaitu penelitian yang dilakukan oleh Anggaraeni (2008) tentang upaya meningkatkan pemahaman konsep bangun ruang melalui pemanfaatan barang bekas sebagai media pembelaaran di kelas V SDN Tutup 1 Blora. Hasil yang didapatkan adalah 1) adanya peningkatan keaktifan siswa, yang meliputi: a) mengemukakan ide dari $16,7 \%$ menjadi $73,1 \%$, b) bertanya dari $20,8 \%$ menjadi $76,9 \%$, c) mengerjakan soal-soal dari $20,8 \%$ menjadi $80,8 \%$. 2) adanya peningkatan kekreatifitasan siswa, yang meliputi: a) melakukan percobaan/demonstrasi dari 16,7\% menjadi 73,1\% dan b) ketepatan menggunakan media pembelajaran dari $25 \%$ menjadi $76,9 \%$. 3) adanya peningkatan hasil belajar siswa, dimana hasil belajar siswa meliputi: a) penguasaan materi dari $12,5 \%$ menjadi $76,9 \%$ dan b) ketepatan menggunakan media pembelajaran dari $25 \%$ menjadi $76,9 \%$.

Adapun penelitian lain, tentang pemanfaatan barang bekas sebagai media pembelajaran di SD, juga dilakukan oleh Rofian (2015) yaitu hasil pemanfaatan barang bekas dalam pembelajaran berkarya seni rupa di SD 1 Gribig Kudus bernilai baik. Dalam pembelajaran yang dilaksanakan di SD tersebut menhasilkan beberapa karya dengan menggunakan barang bekas, yaitu kegiatan merone kalung, iasan ular tangga, hiasan tudung saji, menara dari bungkus rokok, lampion hias, bunga hias. Hal yang terpenting dalam penelitian ini adalah siswa memahami cara memanfaatkan barang bekas tersebut sehingga menadi barang kerainan unik.

Berdasarkan paparan diatas, semakin menekankan bahwa media pembelajaran memegang peranan penting dalam rangka menciptakan learning society, karena melalui media, motivasi belajar akan meningkat. Budiningsih menuliskan dalam kajian tentang media pada Jurnal Cakrawala Pendidikan, media pembelajaran di SD masih 
menggunakan media yang sederhana, dimana alat- alat tersebut dapat dibuat sendiri oleh guru atau siswa yang bersumber dari bahan bahan yang murah dan mudah diperoleh. Media yang sederhana itu penting bagi perkembangan berfikir siswa SD, sebagaimana disarankan oleh Gagne agar siswa belajar mulai dari hal yang sederhana menuju kompleks. Ausubel menyarankan agar siswa dalam belajar belajar, hendaknya dimualai dari apa yang telah mereka ketahui terlebih dulu. Anak usia SD yang sebgaian besar masih dalam taraf berpikir operasional konkret maka hendaknya diberikan kegiatan belajar atau media pembelajaran dengan memanfaatkan benda nyata yang ada disekitarnya. Jadi pemilihan media yang sederhana bukan semata- mata karena harganya murah, tetapi didasarkan pula atas kepentingan perkembangan belajar siswa.

Dengan demikian, berdasarkan masalah yang ada di SD terkait dengan pembuatan media pembelajaran kreatif serta kaian tentang pemanfaatan media pembelaaran sederana dan kreatif dari barang bekas, maka disusunlah sebuah kegiatan pelatihan untuk membantu permasalah sasaran/ mitra. Kegiatan yang direncanakan ini berjudul "Pelatihan pembuatan media pembelajaran kreatif dari barang bekas bagi guru SD di Kecamatan Wonosalam Jombang". Pelatihan ini diharapkan dapat memberikan motivasi bagi guru- guru SD untuk meningkatkan kualitas pembelajaran yang kreatif, efektif, dan menyenangkan. Hal ini mengingat media pembelajran sangat penting dalam rangka menyampaikan pesan berupa informasi/ pengetahuan kepada siswa. Alternatif kegiatan ini dimaksudkan untuk membantu memberikan solusi permasalahan pembelajaran di SD dan memberikan kontribusi yang positif untuk kualitas pendidikan dasar di Jombang, khususnya di wilayah Kecamatan Wonosalam.

\section{METODE}

Kegiatan pelatihan ini dilakukan dengan metode pelatihan dan pendampingan. Pelatihan dimaksudkan untuk memberikan wawasan kepada Guru guru di Wonosalam Jombang tentang media pembelajaran dari barang bekas. Kemudian, dosen dibantu mahasiswa melakukan pendampingan pembuatan media pembelajaran dari barang bekas. Selesainya pelaksanaan pelatihan pembuatan media pembelajaran dari barang bekas ini diharapkan mampu menyelesaikan permsalahan guru, yakni tentang pembuatan media pembelajaran yang kreatif, efektif dan efisien.

Adapun secara rinici target luaran yang diharapkan tercapai setela pelatihan ini sebagai berikut, (1) Peserta memiliki keterampilan dalam membuat media pembelajaran dari barang bekas, serta (2) Peserta dapat memanfaatkan barang bekas untuk media pembelajaran di SD sehingga dapat memudahkan dalam kegiatan pembelajaran. Adapun gambaran kegiatan yang dilakukan dapat dirinci sebagai berikut.

1. Tahap Persiapan

Dalam tahap persiapan dilakukan hal hal senagai berikut, yaitu koordinasi dengan mitra/ sasran, observasi kondisi mitra, penyiapan materi pelatihan, penyiapan alat dan bahan berua barang bekas untuk membuat media pembelajaran, penyusunan jadwal pelatihan

2. Tahap Pelaksanaan 
Pada tahap pelaksanaan ini, dilakukan hal- hal sebagai berikut : sosialisasi pembuatan media pembelajaran dari barang bekas, pelatihan dan pendampingan pembuatan media pembelajaran dari barang bekas, pemberian angket kepada mitra, sebagai bentuk tindakan evaluasi pelaksanaan PKM ini.

Berdasarkan bidang keahlian masing-masing anggota tim, maka lingkup tugas dan tanggung jawab dalam menyelesaikan pekerjaan ini dipaparkan sebagai berikut, (1) Menyusun materi pelatihan, (2) Memberikan pemaparan tentang materi tentang pemanfaatan barang bekas untuk media pembelajaran di SD, (3) Memberikan pendampingan pembuatan media pembelaaran kreatif dari barang bekas untuk pembelajaran di SD.

\section{HASIL DAN PEMBAHASAN}

Persiapan Pelaksanaan Pengabdian Masyarakat bagi Kelompok Kerja Guru Kecamatan Wonosalam - Jombang dilaksanakan sejak bulan April 2018. Tim secara berkala mengadakan pertemuan guna membahas persiapan pengabdian masyarakat yang mengambil tompik tentang pelatihan pembuatan media kreatif dari barang bekas. Selama bulan Mei, tim secara intensif melakukan pertemuan guna meyusun bahan pelatihan yang terdiri dari 3 materi meliputi, (1) Hakekat Media Pembelajaran di SD; (2) Macam Kreasi Media dari Barang Bekas; (3) Merancang Media Pembelajaran Kreatif. Penyusunan bahan pelatihan ini mengalami revisi pada beberapa pertemuan, agar didapatkan materi kegiatan yang lengkap, sesuai dengan tujuan, dan mampu memberikan inspirasi bagi guru- guru SD di Kecamatan Wonosalam. Hingga akhirnya diperoleh finalisasi bahan pelatihan pada awal Juli 2018 dengan pembagian unit yang diampu secara jelas.

Berdasarkan kesepakatan antara pihak jurusan PGSD dengan Kelompok Kerja Guru SD di Kecamatan Wonosalam, maka pelaksanaan kegiatan Pengabdian Kepada Masyarakat dapat terlaksana pada 20-23 Juli 2018. Pada awal acara seluruh peserta diberikan sambutan dan pengarahan oleh Kepala Dinas Pendidikan Kota Jombang, Ketua Jurusan PGSD UNESA, dan Ketua KKG Kecamatan Wonosalam agar para guru bersungguh- sungguh dan semakin termotivasi dalam memajukan pendidikan khususnya di kecamatan Wonosalam Jombang. Para peserta kemudia masuk ke dalam kelas- kelas yang telah ditentukan sebelumnya oeh panitia. Kelas dibagi menjadi kelompok kelas rendah dan kelompok kelas tinggi. Semua kelompok kelas akan mendapatkan pelatihan terkait dengan topik- topik yang sudah disipakan oleh Tim Pengabdian Kepada Masyarakat Jurusan PGSD FIP UNESA.

Pelaksanaan pelatihan diawali dengan diskusi tentang pemanfaatan media pembelajaran selama ini, yang telah dilakukan oleh guru - guru di Kecamatan Wonosalam. Diskusi diawal pertemuan ini dimaksudkan untuk menyatukan pendapat dan analisis permasalahan media yang dialami oleh guru- guru tersebut. Diskusi berlangsung efektif, karena para guru tidak segan untuk menceritakan pengalamanpengalaman selama menggunakan media. Dari diskusi awal diketahui baha sebagian besar guru- guru di Wonosalam hanya menggunakan media siap pakai, atau media nyata dari alam, seperti batu, bunga, dan lain- lain. Guru- guru tidak sangat jarang 
memiliki waktu untuk merancang media pembelajaran sendiri. Alasan dari guru- guru tersebut adalah tidak ada waktu, malas, membutuhkan banyak biaya, karena tidak jarang untuk membuat media pembelajaran, guru- guru harus mencari duru di Kota Jombang atau Surabaya, sehingga dirasa kurang efektif. Padahal guru bisa mengkreasikan barang- barang bekas yang banyak dijumpai sehari- hari untuk dijadikan media pembelajaran. Maka diarasa sangat tepat apabila tim PGSD UNESA mengadakan pelatihan pembuatan media pembelajaran dari barang bekas ini.

Setelah diskusi sebagai apersepsi pelatihan dilakukan, selanjutnya adalah pemaparan materi oleh Balak Ganes Gunansyah, M.Pd tentang hakikat media pembelajaran kriteria memproduksi media yang baik. Selanjutnya materi tentang macam- macam kreasi media dari barang bekas dipaparkan oleh Ibu Putri Rachmadyanti, M.Pd. Kreasi media pembelajaran dari barang bekas disesuaikan dengan pembelajaran di Sekolah Dasar. Disamping itu, para peserta pelatihan diberikan handout tentang kreasi media pembelajaran dari barang bekas. Materi selanjutnya adalah tentang merancang media pembelajaran yang disamapikan oleh Bapak Drs. FX Mas Subagio, M.Pd. Tahap meranang media pembelajaran dari barang bekas ini dimulai dari menentukan materi, jenis media yang dibuat dan penggunaan media pembelajaran tersebut di kelas.

Setelah ketiga materi disajikan, peserta pelatihan diberikan waktu untuk praktik merancang dan membuat media pembelajaran. Peserta pelatihan dibentuk menjadi beberapa tim, dalam 1 tim terdiri dari 4-5 orang. Setiap tim diberikan alat dan bahan yang bebas untuk digunakan untuk membuat media. Bahan- bahan yang disipakan adalah kertas kardus bekas, botol bekas,kain perca, sisa kertas potongan kado. Adapun untuk alat yang disiapkan untuk menunjang praktek pembuatan media adalah gunting, lem, kertas origami, kertas manila, double tip, spidol, dan lain- lain. Praktek merancang dan membuat media pembelajaran dilakukan selama 1 jam. Tim PKM PGSD UNESA mendampingi praktek yang yang dilakukan oleh peserta pelatihan. Peserta pelatihan yang terdiri dari guru senior maupun guru muda saling berbaur untuk merancang dan membuat kreasi media dari barang bekas. Para peserta pelatihan nampak antusias , mengingat alat dan bahan sangat mudah untuk diperoleh dalam kehidupan sehari- hari.

Setelah praktek merancang dan membuat media pembelajaran selesai, setiap tim diberikan kesempatan untuk mempresentasikan hasil kerja tim. Hasil pembuatan media pembelajaran yang telah dihasilkan oleh tim guru- guru Kecamatan Wonosalam meliputi, tempat sampah organik dan anorganik dari kardus bekas, oster 3 dimensi dari kardus bekas, miniatur lingkungan buatan dari kardus bekas, ayang anggota keluarga dari kardus bekas, miniatur ekosistem laut, maket sederhana dari kardus. Agar lebih jelas, berikut disajikan tabel hasil rancangan dan pembuatan media pembelajaran dari barang bekas oleh Guru- guru SD di Kecamatan Wonosalam.

Tabel 1. Rekapitulasi Hasil Merancang dan Membuat Media Tim KKG Guru SD Kecamatan Wonosalam Jombang 


\begin{tabular}{|c|c|c|c|}
\hline No & Nama Tim & Hasil & Penilaian \\
\hline 1 & $\mathrm{~L} \mathrm{~F}, \mathrm{~S}, \mathrm{P}$ & $\begin{array}{l}\text { 1. Peta Indonesia } \\
\text { dari bahan kardus } \\
\text { bekas miniatur } \\
2 . \\
\text { ekosistem laut dari } \\
\text { bahan karuds bekas }\end{array}$ & $\begin{array}{l}\text { Peta yang dibuat ukuran cukup } \\
\text { besar, dan sangat sederhana karena } \\
\text { hanya membutuhkan spidol dan } \\
\text { kardus, namun perlu ditambahkan } \\
\text { warna pada peta, bingkai yang rapi } \\
\text { supaya lebih menarik } \\
\text { Untuk miniatur ekosistem ukup } \\
\text { bagus, namun belum lengkap untuk } \\
\text { menjelaskan tentang ekosistem } \\
\text { laut }\end{array}$ \\
\hline 2 & $\mathrm{~T}, \mathrm{O}, \mathrm{P}$ & Jam Gadang & $\begin{array}{l}\text { Jam yang dibuat cukup sederhana, } \\
\text { terbuat dari kardus yang } \\
\text { menyerupai bentuk Jam Gadang di } \\
\text { Sumatera Barat versi mini. Sudah } \\
\text { bagus, namun perlu } \\
\text { dipertimbangkan penggunaan } \\
\text { kelas, karena media yang kecil. }\end{array}$ \\
\hline 3 & $\mathrm{~K}, \mathrm{P}, \mathrm{M}$ & $\begin{array}{lr}\text { Puzzle } & \text { Peta } \\
\text { Indonesia } & \text { dari } \\
\text { kardus bekas } & \end{array}$ & $\begin{array}{l}\text { Puzzle yang dibuat cukup bagus } \\
\text { dan sesuai untuk menambah } \\
\text { motivasi belajar peta bagi anak. } \\
\text { Namun puzzle akan lebih awet jika } \\
\text { diberi bingkai, dan setiap tepi } \\
\text { potongan puzzle diberi selotip atau } \\
\text { isolasi agar tidak mudah robek } \\
\text { ketika digunakan siswa. }\end{array}$ \\
\hline 4 & $\mathrm{R}, \mathrm{A}, \mathrm{P}, \mathrm{L}$ & $\begin{array}{l}\text { Wayang Anggota } \\
\text { Keluarga dari kardus } \\
\text { bekas }\end{array}$ & $\begin{array}{l}\text { Media wayang yang dibuat bagus } \\
\text { dan karakter yang dibuat mewakili } \\
\text { anggota keluarga. Alat dan bahan } \\
\text { yang dibuat sederhana, meliputi } \\
\text { kardus bekas, sedotan dan kertas } \\
\text { origami, }\end{array}$ \\
\hline 5 & $\mathrm{SH}, \mathrm{D}, \mathrm{N}, \mathrm{S}$ & $\begin{array}{l}\text { Miniatur lingkungan } \\
\text { buatan dari kardus } \\
\text { bekas }\end{array}$ & $\begin{array}{l}\text { Media yang dibuat cukup bagus, } \\
\text { hanya kurang jelas dan kurang } \\
\text { besar. Media yang dibuat belum } \\
\text { terlalu menunjukkan tentang } \\
\text { konsep lingkungan buatan }\end{array}$ \\
\hline 6 & $\mathrm{SW}, \mathrm{NW}, \mathrm{R}$ & $\begin{array}{l}\text { Maket dari bahan } \\
\text { kardus bekas }\end{array}$ & $\begin{array}{l}\text { Maket yang dibuat sederhana, dan } \\
\text { mudah dibuat. Pemberian tugas } \\
\text { membuat maket ini bisa dikerjakan } \\
\text { bersama- sama dengan siswa agar } \\
\text { siswa semakin aktif }\end{array}$ \\
\hline
\end{tabular}




\begin{tabular}{|c|c|c|c|}
\hline No & Nama Tim & Hasil & Penilaian \\
\hline 7 & $\mathrm{~S}, \mathrm{PS}, \mathrm{D}, \mathrm{A}$ & $\begin{array}{l}\text { Tempat sapu lidi dari } \\
\text { kardus dan botol } \\
\text { bekas }\end{array}$ & $\begin{array}{l}\text { Tempat sapu lidi yang dibuat dari } \\
\text { gabungan kardus bekas dan botol } \\
\text { bekas ini bagus. Media cukup kuat } \\
\text { dan tahan lama. Media yang dibuat } \\
\text { bisa langsung diaplikasikan untuk } \\
\text { menanamkan karakter cibta } \\
\text { kebersihan melalui media yang } \\
\text { sederhana }\end{array}$ \\
\hline 8 & $\mathrm{~S}, \mathrm{~S}, \mathrm{G}$ & $\begin{array}{l}\text { Poster } 3 \text { Dimensi } \\
\text { dari bahan kardus } \\
\text { bekas }\end{array}$ & $\begin{array}{l}\text { Poster yang dibuat kreatif karena } \\
\text { menunjukkan konsep IPA seperti } \\
\text { bagian- bagian tanaman mellaui } \\
\text { poster. Hanya poster perlu diberi } \\
\text { bingkai agar rapi }\end{array}$ \\
\hline 9 & $\mathrm{P}, \mathrm{N}, \mathrm{N}, \mathrm{T}$ & $\begin{array}{l}\text { Temat sampah } \\
\text { anorganik } \\
\text { organik dari bahan } \\
\text { kardus bekas }\end{array}$ & $\begin{array}{l}\text { Tempat sampah yang dibuat versi } \\
\text { mini, untuk menjelaskan tentang } \\
\text { konsep organis dan anorganik. Jika } \\
\text { ada kesempatan lagi, bisa lebih } \\
\text { diperbesar ukuran media nya agar } \\
\text { terlihat jelas oleh siswa }\end{array}$ \\
\hline
\end{tabular}

Semua tim yang membuat media pembelajaran diberikan penguatan oleh TIM PKM PGSD UNESA. Hal ini dimaksudkan untuk menambah motivasi peserta pelatihan untu mengaplikasikan keterampilan yang telah didapatkan selama mengikuti pelatihan pembuatan media pembelajaran dari bekas ini. Hal ini untuk memberikan penguatan tentang pentingnya membuat media yang menarik dan kreatif untuk mengembangkan kemampuan siswa. Hal ini sesuai dengan fungsi media pembelajaran menurut Levi dan Lentz (dalam Musfiqon, 2012:33) menerangkan bahwa media pembelajaran memiliki fungsi afektif, atensi, kognitif, serta kompensatoris dimana media pembelajaran mampu membuat siswa tertarik dan membangkitkan minat belajar siswa. Sebelum menutup kegiatan, semua peserta diberikan angket dalam rangka menjaring tanggapan peserta pelatihan sebagai bahan evaluasi untuk Tim PKM PGSD UNESA yang akan dituliskan dalam laporan akhir kegiatan Pengabdian Kepada Masyarakat tahun 2018. Adapun hasil angket yang diberikan kepada 36 responden, pada gelombang 1 dan gelombang 2 didapatkan hasil sebagai berikut. 


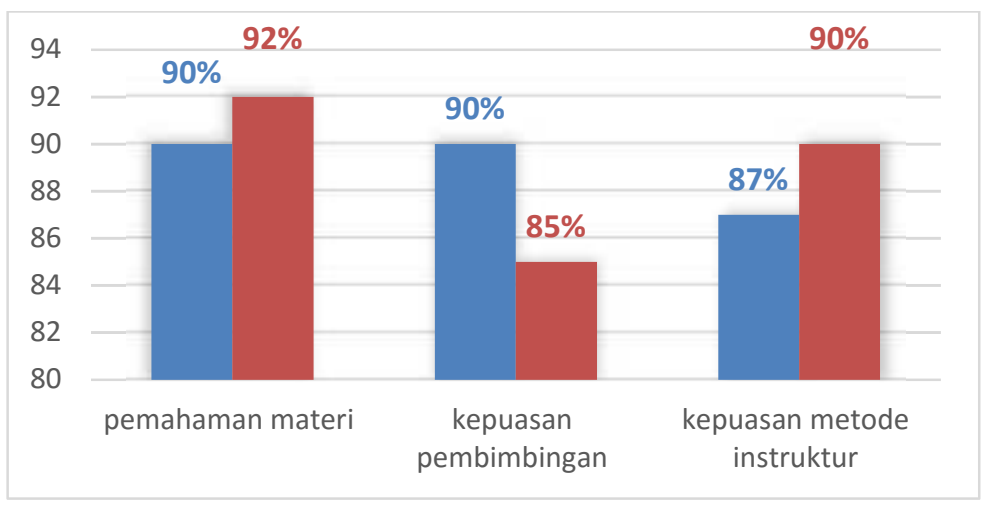

Gambar 1 Hasil Angket Peserta Pelatihan

Berdasarkan diagram di atas daat diketahui bahwa sebagian besar peserta pelatihan puas dengan pelatihan yang diberikan. Namun aspek yang dirasa perlu mendapatkan perhatian sebagai bahan evaluasi adalah bimbingan yang diberikan instruktur perlu lebih mendalam dengan waktu yang diberikan saat membimbing praktek merancang dan membuat media pembelajaran cukup lama. Hal ini diperkuat dengan adanya saran dan kritik yang dituliskan oleh peserta pelatihan bahwa waktu yang diberikan pada saat praktek langsung pembuatan media waktunya perlu ditambah lagi, mengingat ada bebarapa tim yang belum selesai pembuatan media pembelajarannya.

\section{KESIMPULAN}

Berdasarkan capaian kemajuan pelaksanaan PKM ini dapat disimpulkan bahwa pelatihan pembuatan media dari barang bekas di SD ini sangat dibutuhkan oleh para guru yang sedang berupaya meningkatkan kapasitas dan kapabilitasnya dalam meningkatkan mutu pembelajaran. Selain itu, alat dan bahan yang diperlukan untuk membuat merancang dan membuat media mudah ditemukan dalam kehidupan sehari hari, dan tentunya efisen. Hasil media pembelajaran yang telah dibuat dapat digunakan untuk membantu mengajar siswa baik kelas rendah maupun kelas tinggi. Kegiatan ini diharapkan mampu menambah wawasan dan memotivasi guru untuk semakin meningkatkan kualitas pengelolaan kelas, perencanaan pembelajaran, khususnya dalam kaitannya merancang dan membuat media pembelajaran yang efektif dan efisien. 


\section{DAFTAR PUSTAKA}

Anggraeni, Pramesti Putri. 2008. Upaya Peningkatan Pemahaman Konsep Bangun Ruang melalui Pemanfaatan Barang Bekas sebagai Media Pembelajaran ( PTK di Kelas V SDN Tutup I Blora ). Skripsi thesis, Universitas Muhammadiyah Surakarta.

Arsyad, Azhar. 2014. Media Pembelajaran. Jakarta: P.T. Raja Grafindo Persada

Kustiawan, Usep. 2016. Pengembangan Media Pembelajaran Anak Usia Dini. Malang: Gunung Samudra.

Musfiqon. 2012. Pengembangan Media \& Sumber Pembelajaran. Jakarta : PT Pretasi Pustakarya.

Pribadi, Benny A. 2017. Media dan Teknologi Dalam Pembelajaran. Jakarta: Kencana

Rofian, Ari Widianingrum. 2015. Barang Bekas sebagai Media Penciptaan Karya Seni dalam Pembelajaran Seni Rupa Kelas V SD 1 Gribig Kudus. Jurnal Malih Peddas (Majalah Ilmiah Pendidikan Dasar), PGSD Universitas PGRI Semarang, Vol. 5 NO.2 tahun 2015 ISSN 20885792 (Print), ISSN 2580-513 (Online).

Satrinawati. 2018. Media dan Sumber Belajar. Yogyakarta: Deepublish. 